Article

\title{
Preparatory Bodies as Mediators of Political Conflict in Trilogues: The European Parliament's Shadows Meetings
}

\author{
Ariadna Ripoll Servent * and Lara Panning \\ Department of Political Science, University of Bamberg, 960652 Bamberg, Germany; \\ E-Mails: ariadna.ripoll@uni-bamberg.de (A.R.S.), lara.panning@uni-bamberg.de (L.P.) \\ * Corresponding author
}

Submitted: 20 April 2019 | Accepted: 14 June 2019 | Published: 27 September 2019

\begin{abstract}
Trilogues have become 'normal' structures in European Union (EU) decision-making but their functioning, based on secluded decision-making, makes it difficult to understand how institutional positions are formed and managed and which actors are better positioned to influence policy outputs. These are, however, important questions because, first, a coherent position in trilogues (one that withstands the scrutiny of the Council) enhances the European Parliament's (EP) chances of achieving a favourable outcome following negotiation; second, because it has become more complicated to find a common position within the EP due to increased levels of politicisation and polarisation (especially in the form of Euroscepticism) in EU policy-making. Therefore, this article focuses on preparatory bodies preceding trilogues and the role they play in building Parliament's positions. With the shift of political conflict from plenary to committees and now to shadows meetings, the latter have become de facto decision-making bodies. Not only do they serve to mediate intra-institutional conflict but also to anticipate Council and Commission positions. This article compares the use of shadows meetings in politicised and non-politicised issues. With the use of ethnographic data provided by participant observation and elite interviews, we aim to provide explanations on how these new instruments serve to informally manage politicisation, focusing in particular on the advantages of insularity in highly publicised negotiations.
\end{abstract}

\section{Keywords}

committees; Common European Asylum System; European Parliament; European Union political parties; politicisation; shadows meetings; trilogues

Issue

This article is part of the issue "Out of the Shadows, Into the Limelight: Parliaments and Politicisation", edited by Christine Neuhold (Maastricht University, The Netherlands) and Guri Rosén (University of Oslo, Norway).

(C) 2019 by the authors; licensee Cogitatio (Lisbon, Portugal). This article is licensed under a Creative Commons Attribution 4.0 International License (CC BY).

\section{Introduction}

Trilogues have become 'normal' structures in EU decision-making; however, they are informal negotiations between representatives of Parliament, Council and Commission with no reference in the treaties. The aim of trilogues is to facilitate compromises on legislative proposals before the first or second reading in Parliament. On the political level, Parliament is represented by the rapporteur and shadow rapporteurs; Council by the ambassador of its current
Presidency; and the Commission by a Director-General or a Commissioner. Political trilogues are prepared by technical meetings including, for example, Commission policy officers, MEP assistants and administrative officials (see for example Ripoll Servent \& Panning, 2019; Roederer-Rynning \& Greenwood, 2015, 2017). Given that trilogues are based on secluded decision-making, it is often difficult to understand how institutional positions are formed and managed and which actors are better positioned to influence policy outputs. These are, however, important questions because: first, a coherent 
position in trilogues (one that withstands the scrutiny of the Council) enhances the European Parliament's (EP) chances of achieving a favourable outcome following negotiation; second, because finding a common position within the EP has become more complicated with increased levels of politicisation and polarisation (especially in the form of Euroscepticism) in EU policy-making (Ripoll Servent, 2018; Ripoll Servent \& Panning, 2019). The rise in fringe political parties has also put a strain on the process of (informal) institutionalisation which has over time successfully reduced politicisation and interparty conflict within the EP (Daniel, 2015; Rittberger, 2005; Salvati, 2016).

In view of these shifts, we aim to understand how politicisation is managed in EP committees with a focus on those actors involved in trilogue negotiations (relais actors). The latter are under particular pressure to overcome conflicts and find strong compromises that hold when facing Council and Commission in interinstitutional talks. To this effect, we focus on the way relais actors make use of informal preparatory bodies to find consensus and build Parliament's position. In the EP, preparatory work takes place mostly in so-called 'shadows meetings', gathering the rapporteur and shadow rapporteurs, who are part of the EP's negotiating team in trilogues. In addition, other ancillary actors such as political advisors, assistants, and EP staff are also there to support MEPs. We argue that these bodies have become a better field of conflict management than plenary and committees, since they allow relais actors to hold discussions in a more informal and flexible way, thereby anticipating the positions of Council and Commission and adapting the EP's position during trilogue negotiations. Preparatory bodies have been somewhat overlooked in the literature, even though they have become key fora in which institutional actors form their positions and mediate the increased polarisation and politicisation within and across EU institutions. It is, therefore, important to understand their function in order to establish under which conditions they help or hinder conflict management within legislative committees.

Yet, not all issues are politicised nor do they provoke the same level of conflict between EP groups. Therefore, we argue that the more an issue becomes (or has the potential to become) politicised, the more likely to see relais actors making active use of 'shadows meetings' as instruments of conflict management inside EP committees. To this effect, the article uses ethnographic data provided by participant observation and elite interviews (see the list in the Annex) in order to explore the effects that politicisation has on EP preparations for (and during) trilogues. We compare two legislative negotiations (revision of the statute and funding of EU political parties and foundations [EUPP] and asylum package) to examine the differential effects of (non-)politicisation on the use of shadows meetings and the extent to which these have been actively used by relais actors to diffuse conflict and pre-empt future division. This comparison allows us also to draw patterns of participation in shadows meetings, focusing in particular on the dynamics between mainstream and fringe MEPs.

The first section of the article explores the links between parliamentary coordination instruments aimed at building consensus and the impact that politicisation may have on them. From this, we develop expectations on how the presence or absence of politicisation affects the consensus-building strategies of relais actors when building an EP position within committees and present our methodology. The second part explains the use of shadows meetings in general and explores the impact of politicisation by comparing a case of no politicisation (EUPP) with a case of politicisation (asylum package). The comparison of the two cases leads us then to the conclusion that politicisation does indeed stress the need for seclusion and tends to undermine transparency and the deliberative nature of committees.

\section{Politicisation in Legislative Committees}

Despite politicisation now being a widespread phenomenon, most of the literature has focused on the impact it may have on public opinion and party systems (e.g., De Wilde, Leupold, \& Schmidtke, 2016, and related special issue; Hutter, Grande, \& Kriesi., 2016). We know much less about the impact of politicisation on legislatures and, in particular, legislative committees. Politicisation might not be particularly problematic for plenary, given that the latter's purpose is to act as a public tribune and, therefore, expose ideological conflicts (Slapin \& Proksch, 2010). In contrast, politicisation is inimical to legislative committees, whose goal is to build consensus. Indeed, committees share the necessary conditions for consensus practices to emerge: first, they tend to be insulated from public scrutiny and are, therefore, under less (electoral) pressure when holding debates and finding compromises; second, most legislative committees (and particularly those in the EP) tend to specialise and gather expert members familiar with the technical aspects of their policy field(s); finally, committees are sites where members can nurture their relationships over long periods of time, which facilitates the emergence of an esprit de corps and reciprocity (Sartori, 1987, Chapter 8). These three conditions are particularly relevant to understand EP legislative committees since they are in charge of formulating a mandate for interinstitutional negotiations (i.e., presenting a report that amends the Commission's proposal). Therefore, committees are the loci of internal EP negotiations and in charge of managing inter-party conflicts (Bowler \& Farrell, 1995; Whitaker, 2011; Yordanova, 2013).

Certainly, in normal circumstances, there are environmental aspects that might affect the capacity of committees to act as consensus-builders. First, we know that the institutional conditions leading to consensus are particularly effective with less controversial (policy) issues (Miller \& Stecker, 2008). The lack of controversy under- 
scores these latent institutional conditions and allows them to reach their full potential. On the contrary, if issues become controversial, it is more likely that the work of committees will become more publicised and be exposed to increased external scrutiny. Second, the insulated nature of legislative committees has raised awareness about the trade-off between efficiency and democracy. This has been at the core of criticism in many parliaments, including the EP (Brandsma, 2019; Reh, 2014). As a result, many parliamentary committees have undergone what Fasone and Lupo (2015) refer to as 'forced increased transparency'. Calls for more democracy and accountability in committees has led to the introduction of new rules forcing transparency-for instance by transmitting committee debates online, publishing agendas and minutes, or giving plenary more oversight powers (Brandsma, 2019; Roederer-Rynning \& Greenwood, 2017). The result of increased transparency has been a decrease in their powers and a shift to other decisionmaking bodies characterised by high informality and opacity (Fasone \& Lupo, 2015).

How might politicisation affect the powers and roles of legislative committees and their capacity to build consensus? If we follow De Wilde et al. (2016, p. 4), politicisation can be defined as '(a) the growing salience of European governance, involving (b) a polarisation of opinion, and (c) an expansion of actors and audiences engaged in monitoring EU affairs'. Therefore, politicisation leads to more contestation and polarisation in EU policy-making, particularly when issues are related to the nature and future of European integration. As we have seen, more contestation might potentially undermine the norms of consensus provided by the insulated nature of committees. In addition, politicisation brings with it more (public) scrutiny, which generally leads to calls for transparency and openness.

In order to assess the effects of politicisation and their link to parliamentary coordination instruments, we first examine to what extent an issue has become politicised in EU policy-making and the EP in particular. To this effect, we assess whether the issue is: 1 ) salient (looking for instance at the attention it received inside and outside Parliament); 2) polarising-especially in terms of EU integration; and 3) the focus of external attention leading to the involvement of actors beyond the EP. Once we have established the level of politicisation of a given issue, we explore the linkage between the presence/absence of politicisation and the use of coordination instruments to build the position of Parliament before trilogues. To this effect, we draw four potential paths leading to different uses of 'shadows meetings' (see Table 1).

The first (technical) path takes place in cases where none of the characteristics of politicisation are present. Given the technical nature of the issues at stake, we would expect the necessary conditions for consensus practices to be there-namely, expert MEPs who have regularly worked together and who are able to negotiate in a relatively insulated setting. Therefore, 'shadows meetings' might only be necessary to deal with technical discussions and would not act as an instrument to manage conflict. In the second path, we expect issues to be seen as 'political'. This opens a window for saliency to become an issue in internal negotiations-either by raising the stakes within the EP or by attracting external attention. However, these issues are not perceived as polarising in nature-especially when it comes to the EU integration dimension. In this case, we would expect EP party groups to nominate loyal members as rapporteurs or shadow rapporteurs (Hurka, Kaeding, \& Obholzer, 2015). Internal EP negotiations would then be focused on achieving a minimal-winning coalition to support the EP's mandate before trilogues. Therefore, 'shadows meetings' might be less relevant to reaching an EP position than bilateral contacts among EP groups; given that generally a grand coalition between the European People's Party (EPP) and the Progressive Alliance of Socialists and Democrats (S\&D) is needed to reach a majority, negotiations will focus on the dynamics between the larger groups (Hix \& Høyland, 2013).

Table 1. Paths leading to an EP position before trilogues.

\begin{tabular}{|c|c|c|c|c|c|c|}
\hline & Salience & Polarisation & $\begin{array}{l}\text { External } \\
\text { attention }\end{array}$ & $\begin{array}{l}\text { Type of relais } \\
\text { actors }\end{array}$ & Coalition logic & $\begin{array}{l}\text { Use of shadows } \\
\text { meetings }\end{array}$ \\
\hline \multicolumn{7}{|c|}{ Non-politicised issues } \\
\hline Technical path & No & No & No & Experts & Consensus-seeking & Mostly at technical leve \\
\hline Political path & Yes & No & Depends & Party soldiers & $\begin{array}{l}\text { Minimal-winning } \\
\text { coalition }\end{array}$ & $\begin{array}{l}\text { Few; focus of } \\
\text { negotiations on larger } \\
\text { groups }\end{array}$ \\
\hline \multicolumn{7}{|l|}{ Politicised issues } \\
\hline Control path & Yes & Yes & Yes & Party soldiers & Oversized majority & $\begin{array}{l}\text { Few; political } \\
\text { coordinators in control }\end{array}$ \\
\hline Informality path & Yes & Yes & Yes & Experts & Oversized majority & $\begin{array}{l}\text { High number and main } \\
\text { focus of negotiations }\end{array}$ \\
\hline
\end{tabular}


In highly politicised issues, we can expect negotiations to be particularly difficult and to raise the attention of outside actors such as domestic governments and media, voters and interest representatives. The EP would also expect it to be a more difficult issue to negotiate with the Council since the latter tends to be less pro-integration than Parliament (Kreppel \& Hix, 2003, p. 81). Therefore, EP relais actors have a stake in reaching oversized majorities that give them room for manoeuvre and legitimacy when going into trilogues; the more the EP can unite behind a common position, the greater the chance of success when negotiating with Council (Trauner \& Ripoll Servent, 2016). However, we could imagine legislative committees to handle the pressure of politicisation differently. On the one hand (control path), if an issue is highly contentious, they might prefer to appoint rapporteurs and shadow rapporteurs who are close to their political parties, in order to ensure that they represent the political views of the majority in committee and plenary (Hurka et al., 2015). In addition, committee coordinators might be afraid that delegating negotiations to a small informal group might lead to a majority that unravels when it comes to voting in committee and/or plenary. Therefore, they might want to limit the use of shadows meetings in order to keep control over negotiations. On the other hand (informality path), if issues become highly politicised and receive a lot of external attention, EP relais might prefer to shift the venue of negotiations to a more informal setting to avoid scrutiny and re-create the conditions for consensus-seeking that normally exist in committees. Here, we would expect political groups to nominate MEPs who are perceived as experts in terms of both substance and procedure; this might facilitate the emergence of trust in a highly polarised setting. In this case, the dynamics between relais actors (especially between those belonging to mainstream and non-mainstream groups) might be crucial for the success of internal negotiations (Häge \& Ringe, 2019; Judge \& Earnshaw, 2011).

\section{Methodology}

The data are derived from qualitative interviews with actors in Parliament and Council conducted between March 2017 and March 2019 as well as from observations from a seven-month field-research stay in Brussels (October 2017-April 2018). Interviews were mostly conducted in Brussels and in rare cases via telephone. For the case studies, all rapporteurs and shadow rapporteurs, the involved policy advisors from the party groups and, if the contact was available, officials from the committee secretariats were contacted via email. In addition, we also carried out general interviews on shadows meetings with informants who had worked on many reports or who were recommended by other interviewees and contacts formed during the field research. While at least one actor from most party groups agreed to an interview, European Conservatives and Reformists (ECR),
UK Independence Party-Europe of Freedom and Direct Democracy (UKIP-EFDD) and nearly all Europe of Nations and Freedom (ENF) actors either did not respond to or declined the interview request. In addition, it was more difficult to interview actors from smaller party groups, since they have a higher workload and fewer personnel. Interviewees were asked about the organisation and the conduct of shadows meetings, differences between big and small, Eurosceptic and pro-European party groups as well as other informal arrangements outside of the meetings. Interviews with actors involved in the case studies were asked the same questions, however with a focus on how shadows meetings played out in their particular case. The field research stay was divided into two parts-five months in the Commission and two months in Parliament. The focus lay on participant observation of trilogues and preparatory meetings. The focus of the participant observation was not so much on the content of individual policies but rather on the relationship between participants. The aim was to understand how meetings were organised, how participants interacted and how conflicts were solved. Thus, the observation helped to form a general understanding of shadows meetings and internal dynamics, which facilitated and informed the conduct of interviews and provided background information for our research.

As for case selection, the two files were selected because they varied in our main explanatory factor (politicisation). While the EUPP file was very salient for the political actors inside Parliament, the topic received little external attention outside the trilogue circle. In addition, there was very little polarisation between the different party groups as they all had the same goal: to secure and facilitate funding for their political parties. The asylum package, on the other hand, was not only highly salient inside the EP but had also attracted large attention outside the EU institutions as a result of the so-called 'migration crisis' of 2015-2016. Furthermore, the issue split party groups along deep ideological lines, complicating coalition-formation and consensus-seeking.

It is, therefore, interesting to compare how two files, which were very salient for parliamentary actors, were affected differently by the presence or absence of politicisation. Such a comparison can help us understand how files are handled and negotiated in the EP and how politicisation can influence this process.

\section{Shifting Decisions to 'Shadows Meetings'}

Under the ordinary legislative procedure (co-decision), a legislative initiative from the Commission is referred to the committee in Parliament responsible for negotiations; the latter then writes a committee report amending the Commission's proposal. In accordance with the EP's Rules of Procedure, each legislative proposal is referred to a committee, which then appoints a rapporteur responsible for writing the report (EP, 2019, Rules 47 and 49). It is only after the adoption of the report by the com- 
mittee that the EP can decide to enter into trilogue negotiations (EP, 2019, Rule 69c). To facilitate their work on the report, rapporteurs invite all shadow rapporteurs appointed for a file (EP, 2019, Rule 205a) to so-called shadows meetings, where they discuss amendments proposed by the political groups (EP, 2014b). This informal instrument serves to coordinate positions and facilitates finding a compromise supported by a majority of-or at best all-EP representatives so that Parliament projects a united appearance in trilogue negotiations (EP, 2014b; Ripoll Servent, 2018; Ripoll Servent \& Panning, 2019). The importance of shadows meetings as fora for managing intra-institutional contestation and finding compromise increased considerably following the Treaty of Lisbon (Interview 6). While beforehand, consultation and compromise between groups happened rather spontaneously, nowadays an improved structure supports the organisation of the EP delegation and its preparation for trilogues (Interviews 3, 4, 7). The committee stage remains important because it is there that the compromise brokered in shadows meetings is voted upon (Interview 1, 2). The files are also debated in committee to increase public visibility and to keep other committee members regularly briefed (Interview 6). At the same time, shadows meetings provide a secluded forum that helps balance party group interests outside of the public limelight; therefore, they allow for compromises that would not have been possible had negotiations been held in public committee sessions (Interviews 5, 6, 8).

Rapporteurs-supported in their work by assistants, policy advisors from their party group, the committee secretariat, and the EP's Legal Service-chair shadows meetings (Interview 1, 5). Shadows are also supported by the staff of their group (Interview 8) but, while the rapporteur as the chair is always present in shadows meetings, shadows can choose whether to attend or be represented by an assistant or a political advisor from their group. Shadows regularly report back to their group to ensure that they are on the same page (Interview 15, 16), which is especially important when it comes to finding majorities in committee and plenary votes (Interviews 8 , 12, 22; Häge \& Ringe, 2019; Judge \& Earnshaw, 2011).

The meetings can be divided into shadows meetings before the committee vote and shadows meetings during the trilogue negotiation phase. While they are part of the same process and have the same composition, they serve different purposes (Interviews 5, 6, 9, 11, 12). Shadows meetings before the committee vote help the rapporteur and shadows forge a compromise to act as Parliament's common negotiating position. In the meetings, the rapporteurs present their amendments, which are usually circulated in advance, and every shadow (or the person representing the shadow) is given the opportunity to react, signal agreement, ask questions, or suggest their own amendments (Interview 5, 6, 7, 17, 18); the speaking order is allocated according to group size (Interview 10). In general, shadows send their assistants if they agree with the rapporteur's work, only want to suggest small changes, or if the file is of lesser importance to their group (Interview 12,13, own observation). If they want major changes or have important amendments, attending themselves gives greater weight to their demands. Joining shadows meetings might prove crucial to smaller party groups: Those who engage actively in the discussions and make their voices heard often get amendments that are relevant to them, as long as they do not contradict the largest groups' interests (Interview 11, 12, 15, 17; Häge \& Ringe, 2019). Thusdespite being in the minority-they might manage to shift the compromise and bring it closer to their position.

This dynamic is accentuated by the composition of shadows meetings: since each party group is only represented by one shadow (or their respective assistant/political advisor), the size of the group matters less than in committee; the end result might depend rather on personality, persuasion, or group dynamics during the meetings (Interviews 7, 9, 11, 12; Häge \& Ringe, 2019). While every group is given the floor in shadows meetings, the rapporteur generally has consulted the other party groups prior to the meeting. These pre-consultations serve to actively involve EPP and/or S\&D as the two largest groups since at least one of them is needed to ensure the success of the final compromise when it goes to a vote in committee (Interview 12,13,14). Since plenary has to implicitly or explicitly confirm the trilogue mandate (EP, 2019, Rule 69c), a compromise supported by a small majority risks losing the vote because of defectors from their own party group. This is not unlikely during plenary votes as, outside of shadows meetings and committee sessions, both expert and non-expert MEPs are involved in the vote and might follow other logics of voting behaviour compared to committee members (Faas, 2003; Ringe, 2010). Thus, rapporteurs have an incentive to forge a broad majority, involving as many shadows as possible (Interview 5).

In comparison, shadows meetings during trilogues are primarily used for finding common strategies to defend Parliament's position in trilogues or to discuss the trilogue agenda (Interviews 3, 5, 9). The role of shadows is to ensure that the rapporteur represents the agreed compromise (Interview 6) and includes the points important to their political group (Interview 9, 11).

In sum, although legislative committees are formally in charge, most negotiating work is carried out in shadows meetings; 'the bread and butter of parliamentary work' (Interview 6).

\section{Comparing 'Shadows Meetings' across Policy Issues}

\subsection{Revision of the Statute and Funding of EUPP}

The first regulation governing political parties at European level and the rules regarding their funding entered into force in February 2004 (EP \& Council of the European Union, 2003). For the first time, it entitled European political parties to receive funding from 
the EU's budget (Ripoll Servent, 2018, Chapter 9). The organisation of EUPPs, however, still depended on the national laws of the member state in which a political party was based-a situation seen critically by Parliament (European Parliamentary Research Service, 2018). As a result, the EP $(2006,2011)$ called twice on the Commission to revise the existing regulation. In 2014, a new regulation (EP \& Council of the European Union, 2014) gave EUPPs and foundations a European legal personality and introduced more flexibility in their funding, thereby increasing their visibility and effectiveness. In 2016, Parliament revived the topic: A letter from the EPP, the S\&D, and the Alliance of Liberals and Democrats for Europe group (ALDE) asked the Commission to revise the Regulation and a report from the EP's Secretary-General examined the funding of EUPPs and their foundations. This report was extensively discussed in the EP Committee on Constitutional Affairs (AFCO), resulting in January 2017 in a parliamentary question for oral answer to the Commission (European Parliamentary Research Service, 2018). The question called on the Commission to address MEPs' questions and to present a new legislative proposal addressing suggestions from Parliament (EP, 2017a). During a plenary debate in March 2017, the Commission confirmed a formal review in 2018 that would accommodate Parliament's main concerns (European Parliamentary Research Service, 2018). Despite this announcement, in June 2017 Parliament adopted another resolution encouraging the Commission 'to propose a revision of the regulation as soon as possible' (EP, 2017b). In view of this resolution, Commission President Jean-Claude Juncker (2017) announced a new proposal on EUPPs and foundations in his State of the Union speech in September 2017. The AFCO nominated two co-rapporteurs, Rainer Wieland (EPP) and Mercedes Bresso (S\&D), who presented their draft report on 23 October 2017 (AFCO, 2017a). The amended report was discussed and adopted a month later; along with the vote on the report, the committee decided to enter into trilogue negotiations (AFCO, 2017b). The day before the only trilogue took place in February 2018, the co-rapporteurs briefed AFCO on the progress of inter-institutional negotiations. On 23 March 2018, AFCO adopted the provisional agreement from trilogue negotiations with only one abstention and one vote against it (AFCO, 2018). The text was adopted at the end of April and entered into force in May 2018 (EP \& Council of the European Union, 2018). The long history of the file and Parliament's persistence on its revisions show that the EUPP file was very important for the political groups in the EP. It was highly salient because it directly concerned all political groups in Parliament since they are all members of (at least) one European political party (for a list, see Ripoll Servent, 2018, pp. 206-207).

Although co-rapporteurships are common in AFCO (Interview 21), in this case, the nomination of corapporteurs from the two biggest party groups was meant to send a political signal to the Council and
Commission. It served to demonstrate, on the one hand, the importance of the file for the EP and, on the other, that the EPP and S\&D were united on this issue, which put Parliament in a better position during interinstitutional negotiations (Interviews 19, 20). In general, the decision to appoint two rapporteurs gave the largest groups a chance to exchange views and consult with each other (Interview 19) and, thereby, share the pressure exerted by other actors. Indeed, the internal EP process was rapid with less than two months between the nomination of the co-rapporteurs and the adoption of their report in AFCO. This means that only a limited number of shadows meetings could be organised, which strengthened the focus of the negotiations on the larger groups. Indeed, the presence of two rapporteurs from the largest groups created some difficulties: The EPP and S\&D did not always share the same position on all issues and had different priorities, which led to some disagreements and discussions between the co-rapporteurs during the preparation of their draft report (Interview 20). This dynamic made it difficult for the smaller groups to have a say in the discussions, especially on points that were already difficult between the co-rapporteurs (Interview 21). Therefore, shadows from smaller groups were only able to make a difference in ancillary issues (Interview 19). For instance, ALDE and the Greens pushed to have an obligation for parties to publish information on their website regarding the gender composition of candidate lists and members of European political parties (Interview 18, AFCO, 2017c). The co-rapporteurs accepted their amendments and gender representation was eventually included in the EP mandate. This strategy is not unusual; even if a broad majority has already been secured, rapporteurs try to incorporate as many amendments from other groups as possible in the compromise because it will ensure a positive vote in committee and thereby strengthen the EP's position in trilogues (Interviews 5, 6, 8, 10). In this case, this proved right: Although gender was not a priority for the co-rapporteurs (Interviews 18, 21), it ensured the support of ALDE and the Greens, which led to a broad majority in committee.

The vote on the draft report in the AFCO committee shows that the report was supported by all proEuropean party groups. The ECR and ENF shadows abstained, one ECR MEP voted against it, and no member of the EFDD group was present during the vote (EP, 2017c). Hard Eurosceptic groups often abstain from shadows meetings, either because they refuse to engage with the day-to-day political work in parliament or because mainstream party groups exclude them through a cordon sanitaire (Ripoll Servent \& Panning, 2019). However, all party groups had an interest in this file, as it was about securing financial funding for their European political parties. Indeed, right-wing Eurosceptics were afraid that the proposal would be used to disadvantage them in the upcoming elections in 2019 (Interview 16). Therefore, they did try to get involved and-as is the case for all 
participating parties in shadows meetings-were free to take the floor and present their views (Interview 15, $16,18)$. However, the tacit use of the cordon sanitaire made it difficult for them to participate; although they had good insights that might have helped to improve the proposal, the other actors did not listen to their points (Interview 16). On the contrary, mainstream participants were cautious because they had the impression that hard Eurosceptics were only interested in securing funding (Interview 18). Although the Greens and Confederal Group of the European United Left/Nordic Green Left (GUE/NGL) also disagreed with the Commission's proposal (Interviews 15, 16, 22), the overall conflict did not revolve around the nature of European integration, which prevented a strong polarisation along this dimension and helped groups concentrate on a common goal: ensuring that the reform of the statute was successful in inter-institutional negotiations.

This lack of polarisation might explain why the proposal raised little interest beyond the small circle of rapporteurs and shadows. Indeed, shadows meetings were less relevant than in other occasions; they were helpful to incorporate concerns from the smaller party groups rather than acting as a space to broker compromises. Party groups which disagreed fundamentally with the regulation were listened to but excluded from the larger agreement, which was ultimately secured via a compromise drafted between the co-rapporteurs from the EPP and S\&D with the support of smaller, pro-European party groups. The EUPP file was, thus, a non-politicised issue following a political path: despite its internal salience, the positions of the political groups were not polarised along issues of European integration, which meant that negotiations received little external attention. Therefore, the focus of negotiations focused on the two largest parties, which were key to ensuring the success of the file. It is interesting to see, however, that despite having achieved a bipartisan agreement that warranted them a minimal-winning coalition, they still used shadows meetings to enlarge this support by incorporating some ancillary points that were relevant to smaller parties.

\subsection{The Revision of the Common European Asylum System (CEAS)}

The reform of the EU'S asylum system was among the most contested legislative packages in the 2014-2019 legislature-especially since its main cause (the so-called 'migrant crisis') occupied headlines across the EU for most of those five years (Lavenex, 2018; Trauner, 2016). The issue of migration had held the attention of the EP since autumn 2014, when a series of debates and owninitiative reports underlined the need to tackle the arrival and death of migrants in the Mediterranean; their propensity raised as the number of migrants increased and member states started to discuss potential solutions to address the crisis (e.g., EP, 2014a, 2015a, 2015b, 2015c, 2016). The EP debates served as a counterpoint to the increasingly central role played by the European Council and were often the only chance for Parliament to voice its opinion on these matters. Indeed, the EP was sidelined from the decision on relocation quotas in June and September 2015 (Zaun, 2018) and the EU-Turkey Agreement of March 2016 (Slominski \& Trauner, 2018).

This changed when the Commission decided to issue two sets of legislative proposals aimed at reforming the core of the EU's asylum system; notably, it included a reform of the Dublin Regulation, which establishes the state responsible for asylum applications, and four ancillary texts making up the CEAS-namely the Procedures Regulation (aiming to harmonise common rules for dealing with asylum applications), the Qualifications Regulation (who can receive international protection), the Receptions Directive (how asylum-seekers should be treated in member states) and Eurodac (fingerprinting database). The Commission added new proposals on Resettlement (bringing people in need of international protection to the EU) and an upgrade of the European Asylum Support Office into an asylum agency. The EP managed to form a united position in all the files, which (except for Dublin and Procedures) progressed into trilogues and eventually led to political agreements with the Council. However, the inability of Council to find an agreement on Dublin led to a generalised deadlock and the package was deemed to have failed before the EP elections of May 2019 (Interviews 31, 32, 33). The inability to find an agreement reflected the increasingly polarised positions on immigration in many member states and the impact it had on domestic elections and shifting party systems (for more details on interinstitutional negotiations and the reasons for failure, see Ripoll Servent, 2019).

Therefore, we can consider the asylum package to have been highly politicised: it was perceived as an extremely salient and urgent issue; it centred on conflicts around notions of European integration and solidarity among member states; and it attracted an enormous amount of attention from national media, citizens, civil society, and third countries. This led to well-defined cleavages inside the EP, which was divided also along a clear ideological line-with the right to the centre emphasising issues of border security, while the left-wing groups focused on migrant rights (Interviews 26, 27, 30 ). Finding consensus inside Parliament was seen as a challenge by most groups, but the urgency of the matter and the need to adopt a united front vis-à-vis the Council acted as catalysts inside the civil liberties committee (Interview 24). In order to achieve this united front, shadows meetings became a crucial instrument to find compromises. Their role was particularly important given the 'packaged' nature of these files, which increased the need for coordination across different negotiation teams. This task was rendered more challenging because the files did not always share rapporteurs and shadow rapporteurs (as had been the case in the previous CEAS reform of 2011/2013). Therefore, shad- 
ows meetings were often the place in which to deal with the (technical) overlaps across the files-notably on how to define family members (Interview 31). These shadows meetings gathered mostly staff of the MEPs or their political groups, rather than the MEPs themselves. In general, the files were so complex and politically sensitive, that rapporteurs tended to organise more shadows meetings than usual. For instance, one interviewee reported that, for Dublin, they 'needed 21 to 22, depending on how you count, negotiations rounds. Usually, you have 4 or 5' (Interview 24; Interview 25 reported 27 shadows meetings).

The EP's position across the 'asylum package' was highly influenced by dynamics inside the negotiation teams and the ability of rapporteurs and shadows to manage conflicts in shadows meetings. While the team working on an asylum agency was formed of highly experienced legislators who all worked well together, finding compromises on other files was more difficult. For instance, the ECR rapporteur working on Eurodac was against the CEAS reform and, therefore, refused to cooperate with other rapporteurs or with her own shadows. In other dossiers, the presence or absence of certain shadows led to slightly biased positions. In the case of Qualifications and Resettlement, the EPP was mostly absent from shadows meetings, which resulted in more left-wing reports (Interviews 27, 31). Finally, due to a combination of factors, some of the most complicated negotiations took place in the Procedures Regulation. It was the last file to be negotiated in Parliament, which meant that many outstanding issues (and grudges) had to be dealt with there. In addition, the rapporteur was an Italian MEP from the EFDD, who was not trusted to do a good job as an EP negotiator-both as member of a Eurosceptic political group and because she was largely influenced by Italian politics. She also insisted on holding shadows meetings in Italian (with interpretation), which led to confusion and made it difficult for others to follow the discussions. Therefore, the EPP and S\&D made sure that they found a compromise outside the meetings in order to pass the file in committee (Interviews 23, 30).

In general, compromises in shadows meetings were eventually found among mainstream groups (Interview 31). The ENF was absent from most shadows meetings as a matter of principle (Interviews 24, 28, 30, 33, 34). The EFDD was highly divided, with Italian MEPs trying to participate in shadows meetings, despite knowing that the small size of its national delegation and their political profile would give them little influence. British MEPs (UKIP) were mostly absent, and the Swedish shadow for some files (Winberg) simply opposed any reform of the CEAS (Interviews 25, 29, 31). As for soft Eurosceptic groups such as GUE/NGL and ECR, it depended mostly on the shadow, with some highly active and cooperative (for instance GUE/NGL in Qualifications and ECR in Dublin), while others were mostly excluded from any attempt to find consensus because their positions were too radical (Albiol [GUE/NGL] and, espe- cially, Halla-Aho [ECR] in Procedures; Interviews 24, 25). This, of course, is a well-known strategy of these groups, which participate in shadows meetings but propose extreme amendments, knowing that they will be rejected by mainstream groups; it is a way to notify their opposition and justify a negative vote in committee (Interview 33).

Therefore, we have seen how, in a highly politicised legislative package, shadows meetings were essential to manage conflicts in the EP and to anticipate potential disagreements with Council. At the same time, it also shows how, despite the overlaps between the files and the need to coordinate between negotiating teams, each procedure was a world of its own. In this sense, the composition of the negotiating team was essential to guarantee broader majorities and more effective shadows meetings. In those files where rapporteur and shadows rapporteurs had worked together in the past or had more experience dealing with asylum policies, coordination (both political and technical) was more fruitful than in shadows meetings held by extreme MEPs and/or inexperienced members. Therefore, in those cases where files were dealt with by expert MEPs and fringe parties were absent, there was a more active use of shadows meetings (informality path). In comparison, when fringe parties or Eurosceptic MEPs acted as rapporteurs, there were more attempts by party groups to make agreements outside of shadows meetings (control path).

\section{Conclusion}

This article has presented a comparison of two salient yet very different legislative files-especially when it comes to the presence of politicisation. It shows how parliamentary actors tried to actively find compromises on these files in order to be more effective in trilogue negotiations with the Council and Commission and how important shadows meetings were to finding a common position inside the EP. The EUPP file, on the one hand, was a highly political file for EP actors, as it revised financial regulations for European political parties which directly affected EP party groups. At the same time, it raised fewer issues related to EU integration and little attention from actors outside the EP. As a result, while the nomination of two co-rapporteurs from S\&D and EPP demonstrated the file's importance, it also helped to keep the conflict within the two biggest groups-which diminished the need for shadows meetings or the active involvement of committee and plenary. In the end, the co-rapporteurship system meant that the two biggest groups only needed the smaller groups to secure a broad parliamentary majority in order to prevent a major split of Parliament along party lines and ideologies. As a result, the intra-institutional negotiation process followed a political path that stressed the need for winning coalitions and put the onus on the two larger groups to find an agreement between them; once this was achieved, negotiations with other groups were relatively quick and 
uncontroversial. The asylum package, on the other hand, split Parliament along left-right party lines. It also raised questions about the nature of European integration and the benefit of harmonising asylum policies further (Ripoll Servant, 2019). The controversial, ideologically-charged nature of the package complicated the process of finding compromises, also in shadows meetings. In those cases where rapporteur and shadow rapporteurs had experience in the field and had worked together in the past, shadows meetings were used to gain large majorities. Therefore, while shadows meetings were crucial to ensure the support of the committee on all files by gathering broad majorities inside and across negotiating teams, the 'informality path' was particularly important under conditions of expertise and strong social ties among members of the negotiating team.

What does this tell us about the use of shadows meetings to formulate united positions within legislative committees? First, it seems that the path of informality that has led to secluded decision-making in the form of inter-institutional trilogues (Farrell \& Héritier, 2004; Reh, 2014) has also continued within the EP. We could, therefore, speak of a second layer of informalisation which has now become largely institutionalised inside Parliament. Second, the shift to informal decision-making within legislative committees is particularly present in politicised files. Indeed, politicisation heightens the need for new negotiation fora away from the public limelight. It puts pressure on relais actors to find broad winning coalitions in a more polarised context (both on the left/right and pro/anti-Europe dimensions), which helps to better understand why they make more intensive use of shadows meetings. These conditions seem to apply particularly when the negotiating team is composed of expert mainstream MEPs. It will be important to examine whether these conditions hold in the new parliamentary term-where the presence of more fringe parties and first-timers (two-thirds of MEPs were newly elected in the 2019 elections) might strengthen polarisation and weaken expertise as an essential element of the mainstream groups' political capital.

We see, therefore, a paradox emerging: The more a file is politicised, the more it runs the risk of shifting towards secluded arenas of decision-making and disempowering plenary and committees as fora for deliberation. Seclusion is predominant when mainstream parties dominate negotiations and can ignore the presence of Eurosceptic and fringe parties. Therefore, politicisation stresses indeed the poisoned chalice of transparency in legislative conflicts: More polarisation might call for more transparency and open deliberation but, in reality, it strengthens informality and seclusion. This, in turn, may strengthen the claims of Eurosceptics, who accuse the EP of being opaque and ignoring them. In a time when debates become more polarised and the future of European integration is under pressure, the shift towards more seclusion in the form of informal shadows meetings may reinforce the (perceived) democratic deficit of the EU and widen the gap between European representatives and their voters.

\section{Acknowledgments}

We would like to thank the editors and reviewers of the thematic issue as well as Markus Gastinger and the other participants at the EUSA conference in Denver for their input.

This research has been financed by the DFG (RI 2536/3-1) in the framework of an Open Research Area project on 'Democratic Legitimacy in the EU: Inside the "Black Box" of Informal Trilogues'.

\section{Conflict of Interests}

The authors declare no conflict of interests.

\section{References}

Bowler, S., \& Farrell, D. M. (1995). The organizing of the European Parliament: Committees, specialization and co-ordination. British Journal of Political Science, 25(2), 219-243.

Brandsma, G. J. (2019). Transparency of EU informal trilogues through public feedback in the European Parliament: Promise unfulfilled. Journal of European Public Policy, 26(10), 1464-1483.

Daniel, W. T. (2015). Career behaviour and the European Parliament: All roads lead through Brussels? Oxford: Oxford University Press.

De Wilde, P., Leupold, A., \& Schmidtke, H. (2016). Introduction: The differentiated politicisation of European governance. West European Politics, 39(1), 3-22.

European Parliament. (2006). Resolution of 23 March 2006 on European political parties (P6_TA[2006]0114). Brussels: European Parliament.

European Parliament. (2011). Resolution of 6 April 2011 on the application of Regulation (EC) No 2004/2003 on the regulations governing political parties at European level and the rules regarding their funding (P7_TA[2011]0143). Brussels: European Parliament.

European Parliament. (2014a). Debates-Tuesday, 25 November 2014-Situation in the Mediterranean and the need for a holistic EU approach to migration (0-000078/2014). Retrieved from http://www. europarl.europa.eu/sides/getDoc.do?type=CRE\& reference $=20141125 \&$ secondRef $=$ TTEM-015\& language $=E N \&$ ring $=0-2014-000078$

European Parliament. (2014b). Codecision and Conciliation: A guide to how the European Parliament co-legislates under the ordinary legislative procedure. Brussels: European Parliament. Retrieved from www.epgencms.europarl.europa.eu/cmsdata/ upload/3679a0a2-80fd-43c2-aec8-a72121ff3010/ Guide-ordinary-legislative-procedure-en.pdf

European Parliament. (2015a). Debates: Wednesday, 29 April 2015-Report of the extraordinary European 
Council meeting (23 April 2015)-The latest tragedies in the Mediterranean and EU migration and asylum policies (2015/2660/RSP). Brussels: European Parliament. Retrieved from http://www.europarl. europa.eu/sides/getDoc.do?type=CRE\&reference= 20150429\&secondRef $=\mid$ TEM-003\&language $=E N \&$ ring=P8-RC-2015-0367

European Parliament. (2015b). Debates: Wednesday, 20 May 2015-European agenda on migration (2015/2648/RSP). Brussels: European Parliament. Retrieved from http://www.europarl.europa.eu/sides/ getDoc.do?pubRef=-//EP//TEXT+CRE+20150520+ ITEM-007+DOC+XML+V0//EN\&language $=E N$

European Parliament. (2015c). Debates: Wednesday, 9 September 2015-Migration and refugees in Europe (2015/2833/RSP). Brussels: European Parliament. Retrieved from http://www.europarl.europa.eu/sides/ getDoc.do?pubRef=-//EP//TEXT+CRE+20150909+ ITEM-006+DOC+XML+V0//EN

European Parliament. (2016). Report on the situation in the Mediterranean and the need for a holistic EU approach to migration (P8_TA[2016]0102). Brussels: European Parliament.

European Parliament. (2017a). Question for oral answer to the Commission pursuant rule 128 by Danuta Maria Hübner, on behalf of the Committee on Constitutional Affairs (O-000007/2017/rev.1). Brussels: European Parliament.

European Parliament. (2017b). Resolution of 15 June 2017 on the funding of political parties and political foundations at European level (P8_TA[2017]0274). Brussels: European Parliament.

European Parliament. (2017c). Report on the proposal for a regulation of the European Parliament and of the Council amending Regulation (EU, Euratom) No. 1141/2014 of the European Parliament and the Council of 22 October 2014 on the statute and funding of European political parties and European political foundations (PE 612.066v02-00). Brussels: European Parliament.

European Parliament. (2019). Rules of procedure: 9th Parliamentary term. Brussels: European Parliament. Retrieved from http://www.europarl.europa.eu/ doceo/document/RULES-9-2019-07-02_EN.pdf

European Parliament, \& Council of the European Union. (2003). Regulation (EC) no. 2004/2003 of the European Parliament and of the Council of 4 November 2003 on the regulations governing political parties at European level and the rules regarding their funding (No. L 297). Brussels: European Parliament.

European Parliament, \& Council of the European Union. (2014). Regulation (EU, Euratom) no. 1141/2014 of the European Parliament and of the Council of 22 October 2014 on the statute and funding of European political parties and European political foundations (L 317). Brussels: European Parliament.

European Parliament, \& Council of the European Union. (2018). Regulation (EU, Euratom) 2018/673 of the Eu- ropean Parliament and of the Council of 3 May 2018 amending regulation (EU, Euratom) No 1141/2014 on the statute and funding of European political parties and European political foundations (LI 114). Brussels: European Parliament.

European Parliamentary Research Service. (2018). Statute and funding of European political parties and European political foundations (PE 620.209). Brussels: European Parliamentary Research Service. Retrieved from http://www.europarl.europa.eu/ RegData/etudes/ATAG/2018/620209/EPRS_ ATA(2018)620209_EN.pdf

European Parliament Committee on Constitutional Affairs. (2017a). Minutes extraordinary meeting of 23 October 2017 (AFCO_PV[2017]1023_1). Brussels: European Parliament Committee on Constitutional Affairs.

European Parliament Committee on Constitutional Affairs. (2017b). Minutes meeting of 21 November 2017 (AFCO_PV[2017]1121_1). Brussels: European Parliament Committee on Constitutional Affairs.

European Parliament Committee on Constitutional Affairs. (2017c). Amendments 10-66 (Draft report No. PE613.262v01-00). Brussels: European Parliament Committee on Constitutional Affairs.

European Parliament Committee on Constitutional Affairs. (2018). Minutes meeting of 21 March 2018 (AFCO_PV[2018]0321_1). Brussels: European Parliament Committee on Constitutional Affairs.

Faas, T. (2003). To defect or not to defect? National, institutional and party group pressures on MEPs and their consequences for party group cohesion in the European Parliament. European Journal of Political Research, 42(6), 841-866.

Farrell, H., \& Héritier, A. (2004). Interorganizational negotiation and intraorganizational power in shared decision making: Early agreements under codecision and their impact on the European Parliament and Council. Comparative Political Studies, 37(10), 1184-1212.

Fasone, C., \& Lupo, N. (2015). Transparency vs. informality in legislative committees: Comparing the US house of representatives, the Italian chamber of deputies and the European Parliament. The Journal of Legislative Studies, 21(3), 342-359.

Häge, F. M., \& Ringe, N. (2019). Rapporteur-shadow rapporteur networks in the European Parliament: The strength of small numbers. European Journal of Political Research, 58(1), 209-235.

Hix, S., \& Høyland, B. (2013). Empowerment of the European Parliament. Annual Review of Political Science, 16(1), 171-189.

Hurka, S., Kaeding, M., \& Obholzer, L. (2015). Learning on the Job? EU enlargement and the assignment of (shadow) rapporteurships in the European Parliament. Journal of Common Market Studies, 53(6), 1230-1247.

Hutter, S., Grande, E., \& Kriesi, H. (2016). Politicising Europe. Cambridge: Cambridge University Press. 
Judge, D., \& Earnshaw, D. (2011). 'Relais actors' and co-decision first reading agreements in the European Parliament: The case of the advanced therapies regulation. Journal of European Public Policy, 18(1), 53-71.

Juncker, J.-C. (2017). State of the Union 2017. European Commission. Retrieved from https://ec.europa.eu/ commission/priorities/state-union-speeches/stateunion-2017_en

Kreppel, A., \& Hix, S. (2003). From 'grand coalition' to left-right confrontation: Explaining the shifting structure of party competition in the European Parliament. Comparative Political Studies, 36(1/2), 75-96.

Lavenex, S. (2018). 'Failing forward' towards which Europe? Organized hypocrisy in the Common European Asylum System. Journal of Common Market Studies, 56(5), 1195-1212.

Miller, B., \& Stecker, C. (2008). Consensus by default? Interaction of government and opposition parties in the committees of the German Bundestag. German Politics, 17(3), 305-322.

Reh, C. (2014). Is informal politics undemocratic? Trilogues, early agreements and the selection model of representation. Journal of European Public Policy, 21(6), 822-841.

Ringe, N. (2010). Who decides, and how? Preferences, uncertainty, and policy choice in the European Parliament. Oxford: Oxford University Press.

Ripoll Servent, A. (2018). The European Parliament. London: Palgrave Macmillan.

Ripoll Servent, A. (2019). Failing under the 'shadow of hierarchy': Explaining the role of the European Parliament in the EU's 'asylum crisis'. Journal of European Integration, 41(3), 293-210.

Ripoll Servent, A., \& Panning, L. (2019). Eurosceptics in trilogue settings: interest formation and contestation in the European Parliament. West European Politics, 42(4), 755-775.

Rittberger, B. (2005). Building Europe's Parliament. Ox- ford: Oxford University Press.

Roederer-Rynning, C., \& Greenwood, J. (2015). The culture of trilogues. Journal of European Public Policy, 22(8), 1148-1165.

Roederer-Rynning, C., \& Greenwood, J. (2017). The European Parliament as a developing legislature: Coming of age in trilogues? Journal of European Public Policy, 24(5), 735-754.

Salvati, E. (2016). Towards a European parliamentary class? A proposal for a typology of the Meps. Journal of Comparative Politics, 9(1), 59-74.

Sartori, G. (1987). The theory of democracy revisited. Chatham: Chatham House Publishers.

Slapin, J. B., \& Proksch, S.-O. (2010). Look who's talking: Parliamentary debate in the European Union. European Union Politics, 11(3), 333-357.

Slominski, P., \& Trauner, F. (2018). How do member states return unwanted migrants? The strategic (non-)use of 'Europe' during the migration crisis. Journal of Common Market Studies, 56(1), 101-118.

Trauner, F. (2016). Asylum policy: The EU's 'crises' and the looming policy regime failure. Journal of European Integration, 38(3), 311-325.

Trauner, F., \& Ripoll Servent, A. (2016). The communitarization of the area of freedom, security and justice: Why institutional change does not translate into policy change. Journal of Common Market Studies, 54(6), 1417-1432.

Whitaker, R. (2011). The European Parliament's Committees: National party influence and legislative empowerment. London: Routledge.

Yordanova, N. (2013). Organising the European Parliament: The role of committees and their legislative influence. Colchester: ECPR Press.

Zaun, N. (2018). States as gatekeepers in EU Asylum Politics: Explaining the non-adoption of a refugee quota system. Journal of Common Market Studies, 56(1), 44-62.

\section{About the Authors}

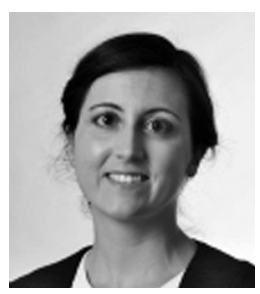

Ariadna Ripoll Servent has been Assistant Professor of Political Science and European Integration at the University of Bamberg since 2013. She is also Visiting Professor at the College of Europe in Bruges. Her research focuses on European integration, EU institutions, and EU internal security policies. Her latest book is The European Parliament (published by MacMillan International Higher Education). Her work has appeared in numerous international journals, including Journal of European Public Policy, Journal of Common Market Studies, and Journal of West European Politics.

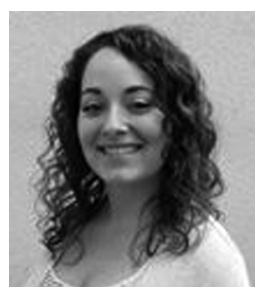

Lara Panning has worked since October 2016 as a Research Fellow for the project 'Democratic Legitimacy in the EU: Inside the "Black Box" of Informal Trilogues" and as a PhD candidate at the University of Bamberg. Her research focuses on informal negotiation processes at EU level, the EU institutions (especially the European Commission and EP) as well as the rise of populism and Euroscepticism. 


\section{COGITATIO}

\section{Annex}

\section{List of Interviews}

\subsection{European Parliament}

Interview 1 (ALDE MEP assistant 1, March 2017)

Interview 2 (S\&D political advisor 1, March 2017)

Interview 3 (EP staff 1, March 2017)

Interview 5 (ALDE political advisor, April 2018)

Interview 6 (ALDE MEP assistant 2, April 2018)

Interview 7 (EPP MEP assistant, April 2018)

Interview 8 (S\&D political advisor 2, April 2018)

Interview 9 (EFDD political advisor, April 2018)

Interview 10 (EFDD MEP assistant, April 2018)

Interview 11 (Greens/EFA political advisors 1\&2, May 2018)

Interview 12 (ALDE MEP assistant 3, May 2018)

Interview 13 (GUE/NGL MEP assistant 1, December 2018)

Interview 14 (EFDD MEP assistant, January 2019)

Interview 15 (GUE group, January 2019)

Interview 16 (ENF group, January 2019)

Interview 17 (EFDD political advisor, January 2019)

Interview 18 (ALDE group, January 2019)

Interview 19 (S\&D group, January 2019)

Interview 20 (EPP group, January 2019)

Interview 21 (GUE group, January 2019)

Interview 22 (Greens/EFA group, January 2019)

Interview 23 (ALDE political advisor, February 2018)

Interview 24 (ALDE MEP assistant 4, February 2018)

Interview 25 (EP staff 2, February 2018)

Interview 26 (EP staff 3, February 2018)

Interview 27 (Greens/EFA political advisor 3, February 2018) 


\section{COGITATIO}

Interview 28 (GUE/NGL MEP assistant 2, February 2018)

Interview 29 (EP staff 2, May 2018)

Interview 30 (S\&D MEP assistant 1, May 2018)

Interview 31 (ALDE political advisor, March 2019)

Interview 32 (EP staff 3, March 2019)

Interview 33 (Greens/EFA political advisor 3, March 2019)

Interview 34 (S\&D MEP assistant 2, March 2018)

1.2. Council of the $E U$

Interview 4 (2 Council officials, 2017) 